\title{
Characterization of gonadotropic cells during continuous and seasonal spermatogenesis of two freshwater fish species: a histochemical and immunohistochemical study
}

\author{
Rafael Henrique Nóbrega • Lázaro Wender Oliveira de Jesus • \\ Renato Massaaki Honji • Maria Inês Borella
}

Received: 12 September 2015/Accepted: 1 August 2016/Published online: 5 August 2016

(C) Springer Science+Business Media Dordrecht 2016

\begin{abstract}
This work describes gonadotropic ( $\mathrm{GtH})$ cells and their morphological and immunohistochemical changes during the spermatogenic cycle of Serrasalmus maculatus (continuous spermatogenesis) and Pimelodus maculatus (seasonal spermatogenesis). $\mathrm{GtH}$ cells, widely distributed in the proximal pars distalis of the adenohypophysis, were characterized as round-shaped cells with eccentric nucleus, and cytoplasm with basophilic secretory granules and a variable number of vacuoles for both species.
\end{abstract}

Rafael Henrique Nóbrega and Lázaro Wender Oliveira de Jesus have equally contributed to this paper.

R. H. Nóbrega

Department of Morphology, Institute of Biosciences, São

Paulo State University, UNESP, Botucatu, Brazil

L. W. O. de Jesus · M. I. Borella

Department of Cell and Developmental Biology, Institute of Biomedical Sciences, University of São Paulo, USP,

São Paulo, Brazil

\section{R. M. Honji}

Department of Physiology, Institute of Biosciences, University of São Paulo, USP, São Paulo, Brazil

\section{I. Borella $(\bowtie)$}

Departamento de Biologia Celular e do Desenvolvimento, Instituto de Ciências Biomédicas, Universidade de São Paulo, Av. Professor Lineu Prestes 1524, São Paulo, SP 05508-000, Brazil e-mail: miborell@usp.br; miborell@yahoo.com.br
Immunohistochemistry against $\beta$-follicle-stimulating hormone (Fsh) and $\beta$-luteinizing hormone (Lh) in adjacent sections showed two separated GtH-producing cell populations, and a third population where both $\mathrm{GtHs}$ are expressed in the same cell for both species. In the seasonal spermatogenesis of P. maculatus, $\mathrm{GtH}$ cells seemed to be more abundant during developing and spawning capable phases. In contrast, no cyclic changes were detected in the continuous spermatogenesis of $S$. maculatus, except for the strong immunoreaction for $\mathrm{Fsh}$ and $\mathrm{Lh}$ in males with intense spermiogenesis. We conclude that changes reported here might reflect the type of spermatogenic cycle (seasonal or continuous) which are under different regulatory mechanisms (environmental and internal cues) controlling the reproduction in these species.

Keywords Teleostei · Pituitary gland · Adenohypophysis · Gonadotropin · Spermatogenesis · Reproduction

\section{Introduction}

In vertebrates, pituitary gonadotropin hormones, follicle-stimulating hormone (FSH) and luteinizing hormone (LH) control testicular development and function by regulating the activity of local signaling systems, for example, sex steroids and growth factors in the testis (Schulz et al. 2010). FSH and LH are 
glycoprotein hormones formed by two subunits; a common $\alpha$ subunit, which is common to FSH, LH and thyroid-stimulating hormone (TSH), and a hormonespecific $\beta$ subunit (Pierce and Parsons 1981). In the pituitary, a subset of adenohypophyseal cells - the socalled gonadotropic cells $(\mathrm{GtH})$ - are responsible to synthesize and secrete the gonadotropin hormones (Agulleiro et al. 2006). Morphologically, these cells can be identified as round-/bulky-shaped cells with eccentric nucleus with variable number of basophilic/ PAS secretory granules and vacuoles in their cytoplasm (Agulleiro et al. 2006).

Functions of fish GtH cells have been widely investigated on gonadal development and reproduction of several species, especially for salmonids (Wu et al. 2012; Weltzien et al. 2004; Shimizu et al. 2003a, b, c). In salmonids, for example, it is well described that Fsh-secreting cells play an important role during early phase of gametogenesis (spermatogenesis and oogenesis), while Lh-secreting cells are important at the final phases, regulating final oocyte maturation, ovulation and spermiation (Schulz et al. 2010). For nonsalmonids, especially tropical fish, these functions are not well described yet. Another interesting aspect of fish $\mathrm{GtH}$ biology is regarding the production of Fsh and Lh. Two secreting GtH cells have been described; one secreting Fsh and the other Lh (Agulleiro et al. 2006; Naito et al. 1993; Nozaki et al. 1990). Interestingly, in some species, a third population, secreting both Fsh and Lh can be found (Kasper et al. 2006; Garcia-Hernández et al. 2002).

Attempting to understand the endocrine regulation of fish reproduction, GtH cells have been studied during reproductive cycle (Vongvatcharanon et al. 2005; Shimizu et al. 2003c), migration (Mukai and Oota 1995) ontogeny/gonadal differentiation (Grandi et al. 2014; Horie et al. 2014; Jesus et al. 2014; Pandolfi et al. 2006), or under experimental conditions (Golan et al. 2014). Considering that most of the existing work have focused on females, very little attention has been given to males, with regard to changes in GtH cells during fish spermatogenesis. Two types of spermatogenesis can be found in teleosts: (1) continuous where spermatozoa are constantly produced during the year (Nóbrega and Quagio-Grassiotto 2007) or (2) seasonal, in which gonads gradually mature, releasing spermatozoa in a specific period of the year (Santana and Quagio-Grassiotto 2014).
Two South American freshwater species were used as experimental models herein: (1) Serrasalmus maculatus (Characiformes, Characidae) is found in most of the Brazilian reservoirs and can easily adapt to lotic environments (Lamas and Godinho 1996). This species has a long reproductive period, frequently more intense in the rainy season, with asynchronous oocyte development (Wildner et al. 2013) and continuous spermatogenesis; (2) Pimelodus maculatus (Siluriformes, Pimelodidae), a freshwater species with potential to aquaculture, widely distributed in the South American river basins. This species display seasonal reproduction between October and January, with some variations due to the influence of abiotic factors (Arantes et al. 2013). Synchronous oocyte development (Wildner et al. 2013) and seasonal spermatogenesis are reported for this species (Santana and Quagio-Grassiotto 2014). In this context, the aim of this study was to investigate and compare the morphological and immunohistochemical (Fsh and Lh) changes in the GtH cells during two different spermatogenic cycles; the continuous spermatogenesis of S. maculatus (Characiformes, Characidae) and the seasonal spermatogenesis of $P$. maculatus (Siluriformes, Pimelodidae). Such changes can be useful to understand the endocrine regulation of spermatogenesis in these species and the GtH rhythmic activity which exerts the overall control over these two types of spermatogenesis.

\section{Materials and methods}

Animals and sampling

Adult males of $S$. maculatus $(n=65)$ and $P$. maculatus $(n=44)$ from 20 to $32 \mathrm{~cm}$ total length were monthly collected at Piracicaba River (Santa Maria da Serra, São Paulo State, Brazil) between November 2003 and April 2005. Specimens were anesthetized with $0.1 \%$ benzocaine (ethyl-paminobenzoate), and body weight (BW, g) was registered. Fish were decapitated at the level of the operculum. After opening the skull, pituitaries connected to the brain were quickly collected and fixed by immersion in Bouin's Solution, during $24 \mathrm{~h}$ at room temperature (RT). In parallel, testes were removed, gonadal weights $(\mathrm{GW})$ were taken to obtain the gonadosomatic index $[\mathrm{GSI}=(\mathrm{GW} /$ 
BW) $\times 100$ ], and medial part of the testes was fixed in $2 \%$ glutaraldehyde and $4 \%$ paraformaldehyde in Sørensen's phosphate buffer $(0.1 \mathrm{M}, \mathrm{pH}$ 7.2) during $24 \mathrm{~h}$ at $4{ }^{\circ} \mathrm{C}$. For statistical analysis, GSI data were submitted to ANOVA followed by Tukey test $(p<0.05)$. All procedures adopted in this study were in agreement with the Institutional Animal Ethics Committee and Brazilian Institute of Environment and Renewable Natural ResourcesIBAMA.

Tissue preparation and histochemistry

After fixation, pituitaries were dehydrated in ethanol, diaphanized in xylene and embedded in Paraplast. Serial parasagittal sections $(5 \mu \mathrm{m})$ were obtained, mounted on poly-L-lysine solution-coated slides and then submitted to histochemistry and immunohistochemistry reactions. Sections were stained with Mallory trichrome to identify pituitary regions and GtH cells. For gonadal analysis, fixed testes were dehydrated and embedded in Historesin (Technovit 7100, Jung HistoResin) as usual procedures (Nóbrega and Quagio-Grassiotto 2007). Longitudinal and sagittal sections were obtained $(3 \mu \mathrm{m})$ and stained with PAS + Hematoxylin + Metanil Yellow as previously (Quintero-Hunter et al. 1991). All slides were mounted and analyzed under light microscopy. The reproductive phases were classified according to the presence of continuous or discontinuous germinal epithelium (GE), as proposed by Grier and Lo Nostro (2000) and Brown-Peterson et al. (2011). In this classification, four reproductive phases are proposed: regenerating, developing, spawning capable and regressing phase. In the regenerating phase, fish are sexually mature but reproductively inactive; the GE is continuous and formed by cysts of spermatogonia (BrownPeterson et al. 2011). The start of meiosis characterizes the developing phase; the GE is continuous and active. Spawning capable phase includes the final steps of spermatogenesis; the GE becomes discontinuous due to spermiation (release of spermatozoa from the cysts toward the lumen) (BrownPeterson et al. 2011). Finally, the regressing phase represents the end of the reproductive cycle or the spawning season; lumen is fulfilled with spermatozoa, and GE is discontinuous with scattered cysts of spermatogonia (Brown-Peterson et al. 2011).
Immunohistochemistry

Pituitary sections ( $n=5$ for each reproductive phase, except for $P$. maculatus at regression stage, where $n=4)$ were submitted to immunohistochemistry reactions using SABC (streptavidin-biotin-peroxidase complex) method (Dako Cytomation $\mathrm{LSAB}_{2}$ System-HRP Liquid DAB-Ref. 0673) as described previously (Honji et al. 2013). Sections were deparaffinized, rehydrated and washed in phosphate-buffered saline (PBS, pH 7.4). After antigen retrieval with citrate buffer ( $\mathrm{pH} 6.0$, at $90{ }^{\circ} \mathrm{C}$ for $10 \mathrm{~min}$ ), endogenous peroxidase activity was blocked by incubating the sections with $3 \%$ hydrogen peroxide in PBS for $30 \mathrm{~min}$. Blocking of nonspecific binding sites was performed using $5 \%$ nonfat dry milk in PBS at RT during $15 \mathrm{~min}$. Subsequently, sections were incubated overnight in a humid chamber at $4{ }^{\circ} \mathrm{C}$ with the following primary antibodies diluted in PBS: antiChum salmon $\beta$-Fsh-Code $8510(1: 1000)$ and antiChum salmon $\beta$-Lh-Code 8506 (1:1000), both produced in rabbit, and kindly donated by Dr. H. Kawauchi (School of Fisheries Sciences, Kitasato University, Iwate, Japan). After primary antibody incubation, sections were rinsed in PBS, submitted to biotinylated secondary antibody (Universal DakoCytomation LSAB + System-HRP, peroxidase), then washed again with PBS and treated with SABC complex. Peroxidase activity was detected with $3,3^{\prime}$ diaminobenzidine (DAB) in a chromogen solution and DAB substrate buffer (imidazole-HCl; Dako Cytomation). Sections were counterstained with hematoxylin and mounted with Erv-Mount (Erviegas, Instrumental Cirúrgico Ltda). For negative control, primary or secondary antibodies were replaced by PBS. The specificity of the antibodies was confirmed by preabsorption tests with the primary antibody and its respective purified antigen, as previously described before (Honji et al. 2013).

\section{Results}

Pituitary gland structure and GtH cells characterization

Pituitaries at developing phase of $P$. maculatus (Fig. 1a), and pituitaries from group I of S. maculatus (prominent testicular cortical region) (Fig. 1c) were 

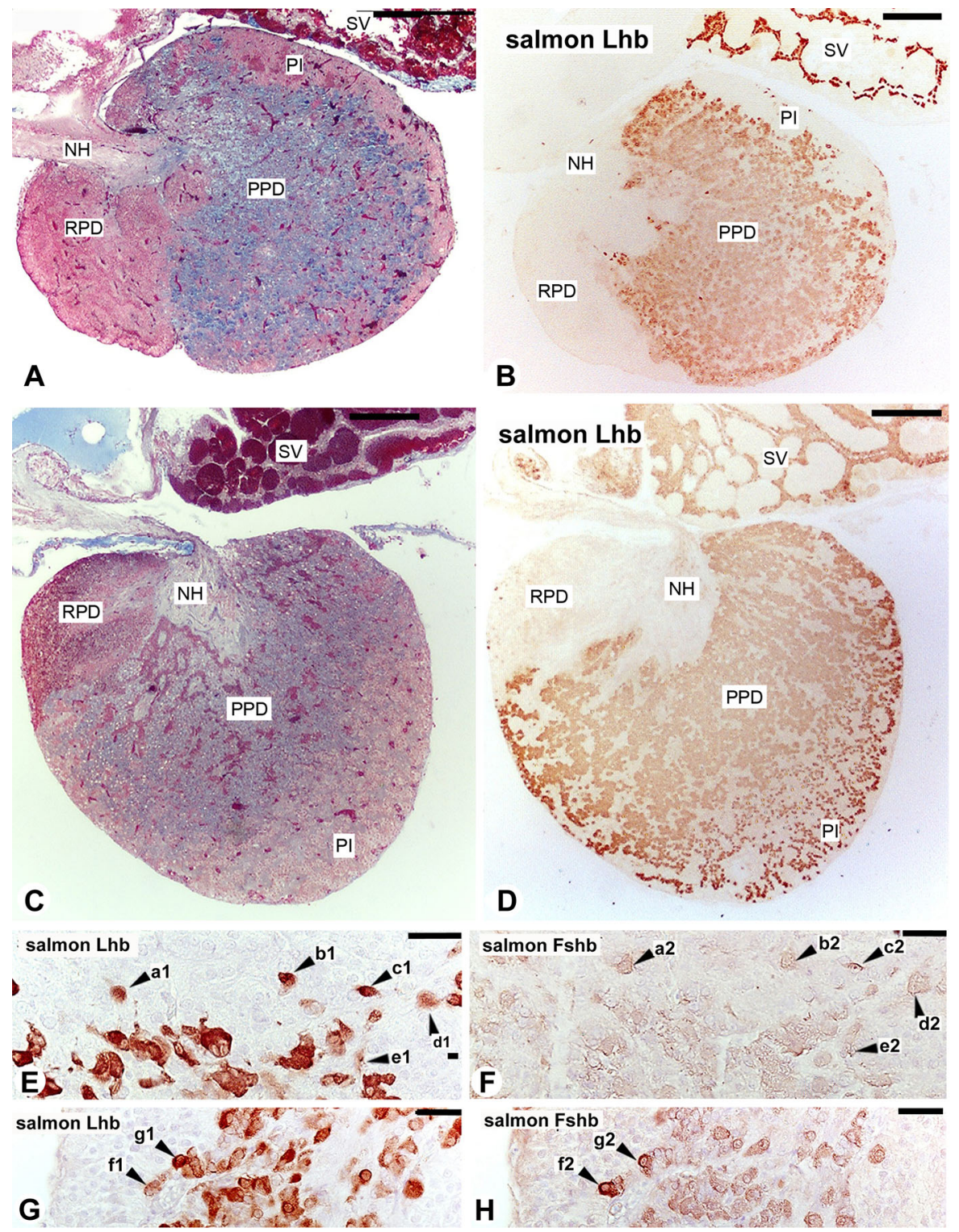

Fig. 1 Pituitary gland structure and $\mathrm{GtH}$ cells characteristics in P. maculatus (a, b, e-h) and S. maculatus $(\mathbf{c}, \mathbf{d})$. a, c Sagittal sections stained with Mallory trichrome. General view of the pituitary gland showing the subdivision of adenohypophysis in rostral pars distalis (RPD), proximal pars distalis (PPD) and pars intermedia (PI), the insertion and branching of the neurohypophysis $(\mathrm{NH})$ and saccus vasculosus $(\mathrm{SV})$. b, d Immunohistochemistry reaction for $\beta$-Lh. The immunopositive cells are widely distributed in the PPD and also in the PI. SV cells are also immunopositive for $\beta$-Lh. $\mathbf{e}-\mathbf{h}$ Serial adjacent

used to describe the gland structure of these species. In both species, pituitaries are composed of two different regions, neurohypophysis $(\mathrm{NH})$ and adenohypophysis (AH) (Fig. 1a, c). The NH, formed by pars nervosa,

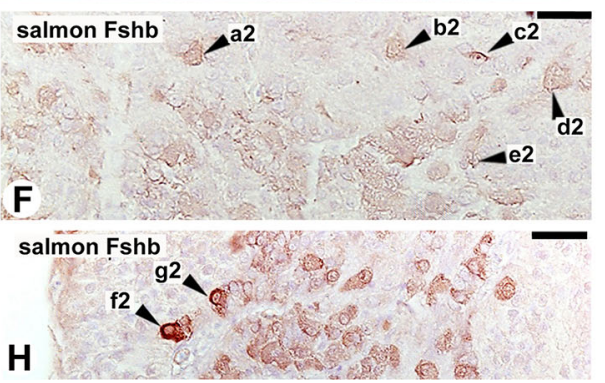

sections showed a third $\mathrm{GtH}$ cell population; co-localization of $\beta$-Lh and $\beta$-Fsh in the same GtH cell of P. maculatus and $S$. maculatus. $\mathrm{E}$ (anti-salmon $\beta$-Lh) and $\mathrm{F}$ (anti-salmon $\beta$-Fsh) are adjacent sections for $P$. maculatus, while G (anti-salmon $\beta$-Lh) and $\mathrm{H}$ (anti-salmon $\beta$-Fsh) are adjacent sections for $S$. maculatus. Arrowheads $a 1, b 1, c 1, d 1, e 1$ in (b) and its correspondent $a 2, b 2, c 2, d 2, e 2$ in $(F)$ indicates the same GtH cell in P. maculatus, while arrowheads $f 1, g 1$ in (c) and $f 2, g 2$ in (g) the same GtH cell in S. maculatus. Bars $200 \mu \mathrm{m}(\mathbf{a}-\mathbf{d})$, $20 \mu \mathrm{m}(\mathbf{e}-\mathbf{h})$

projects many nerve axon termini inside the $\mathrm{AH}$ (Fig. 1a, c). The AH is subdivided into three lobes with different patterns according to their hormoneproducing cells tinctorial properties: rostral pars 
distalis (RPD), proximal pars distalis (PPD) and pars intermedia (PI), (Fig. 1a, c). Both species have the most anterior part of the gland occupied by RPD, which involves the pituitary stalk before its penetration inside the PPD (Fig. 1a, c). The posterior region is formed by PI, characterized by the highest number of NH branches (Fig. 1a, c). PPD is located between RPD and PI and displays a typical basophilic staining as result of the abundance of GtH cells in this region (Fig. 1a, c).

GtH cells in P. maculatus and S. maculatus are elliptical and round, and some are polygonal with an eccentric nucleus and a basophilic cytoplasm-containing vacuoles (Figs. 3, 5). In both species, GtH cells immunoreacted with anti-Chum salmon $\beta$-Fsh and $\beta$ Lh antibodies (Fig. 1b, d, e-h). Fsh- and Lh-immunoreactive cells are distributed along PPD (Figs. 1b, d, 3, 5), as confirmed previously. Interestingly, some GtH cells were found in the PI of both species (Fig. 1b, d). Analyzing serial adjacent sections, we found different populations of Fsh- and Lhimmunoreactive cells, and a third cell population which is immunoreactive for Fsh and Lh at the same time (Fig. 1e-h). A strong immunoreactivity for $\beta$-Lh is seen in the saccus vasculosus for both species (Fig. 1b, d).

GtH cells during the continuous spermatogenesis of $S$. maculatus

S. maculatus has a continuous spermatogenesis, i.e., spermatozoa are constantly produced and released along the year (Fig. 2). Testes did not undergo through remarkable changes during the reproductive cycle, and germ cells at different developing stages of spermatogenesis can be found in the germinal epithelium (GE) (Fig. 2a, d, e). The spawning capable phase is the only reproductive phase detected (Fig. 2). As previously described, $S$. maculatus testis is organized in two morphofunctional regions - the medullar and cortical regions (Fig. 2a, d; Nóbrega and Quagio-Grassiotto 2007). The medullar region is characterized by a continuous GE with cysts at different stages of spermatogenesis (Fig. 2e; Nóbrega and Quagio-Grassiotto 2007). Spermatogenesis also takes place in the cortical region, but the main feature of this region is the storage of spermatozoa (Fig. 2a-d). The cortical region has a discontinuous GE, characterized by scattered cysts of spermatogonia separated by cytoplasm of Sertoli cells (Fig. 2b, c; Nóbrega and Quagio-Grassiotto 2007). Although all specimens were at spawning capable phase, two groups could be found according to the histological analysis (Fig. 2a, d) and GSI (Fig. 2f). In group I, males exhibited testes with prominent cortical region, which is fulfilled with spermatozoa (Fig. 2a). In this group, GSI is high when compared to the group II, in which animals did not show prominent cortical region in their testes (Fig. 2d).

In these two groups, GtH cells were evaluated according to their morphology and immunoreactivity for $\beta$-Lh and $\beta$-Fsh (Fig. 3). In males of group II, GtH cells showed the common features of teleost $\mathrm{GtH}$ cells, as described previously (see above). Moreover, these cells have small and few vacuoles in their cytoplasm (Fig. 3b). On the other hand, in males of group I (prominent cortical region), the vacuoles become larger, and almost all GtH cells showed some degree of vacuolization in their cytoplasm (Fig. 3a). GtH cells with few and small vacuoles are rare in these males (group I) (Fig. 3a). With respect to the immunohistochemistry, a strong signal for $\beta$-Lh- and $\beta$-Fsh is found in the GtH cells which presented few and small vacuoles (group I) (Fig. 3c, e). In the group II, when GtH cells have large vacuoles in their cytoplasm, the immunostaining for both GtHs (Fsh and Lh) is weak (Fig. 3d, f).

GtH cells during the seasonal spermatogenesis of $P$. maculatus

Four testicular phases were described during the annual reproductive cycle of $P$. maculatus: regenerating, developing, spawning capable and regressing phase (Fig. 4a-d). These changes were also reflected in the GSI (Fig. 4e). In the regenerating phase, testis is predominately composed by cysts of spermatogonia, which form a continuous GE in this phase (Fig. 4a). As the start of meiosis (developing phase), the continuous GE presented cysts at different stages of spermatogenesis (e.g., spermatogonia, spermatocytes and spermatids; Fig. 4b). As spermatogenesis progresses, the GE becomes gradually discontinuous due to the spermiation (release of spermatozoa from the cysts) which is typical of the spawning capable phase (Fig. 4c). In this phase, as consequence of spermiation, the testicular lumen is large and fulfilled with spermatozoa (Fig. 4c). 

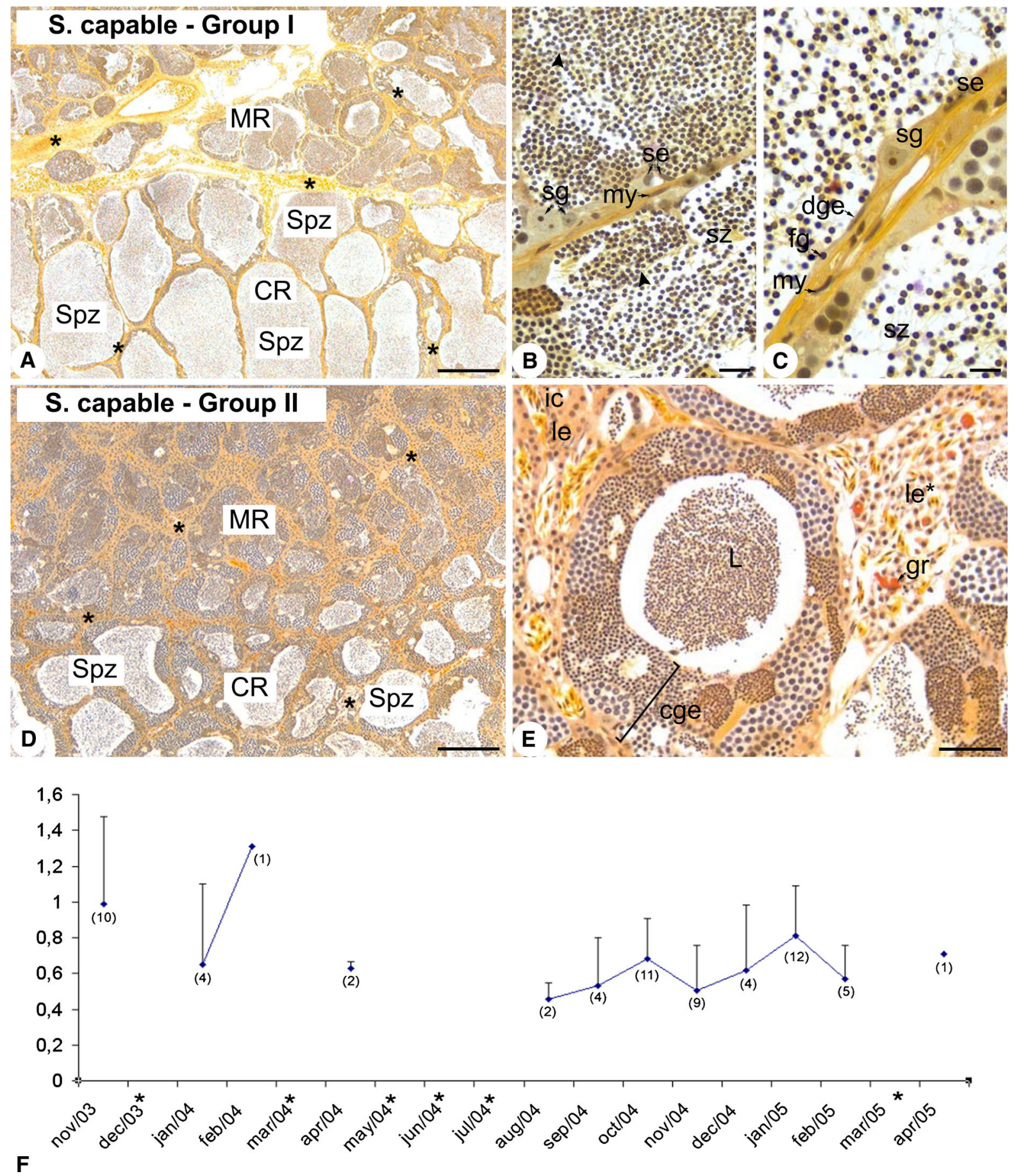

Finally, in the regressing phase, which represents the end of the reproductive cycle, the GE is discontinuous; the testicular lumen presented less spermatozoa when compared to the previous phase; and the interstitial compartment is disorganized (Fig. 4d). Interestingly, we also detected cyclical changes in the GtH cells during the annual reproductive cycle of $P$. maculatus males. When 
४Fig. 2 Reproductive groups and GSI in S. maculatus. Sections were stained with PAS + Hematoxylin + Metanil Yellow. a Males of group I have a well-developed cortical region (CR) and large testicular lumen fulfilled with spermatozoa (Spz). b, c High magnification of the cortical region. b Intense spermiation (arrowheads) and lumen fulfilled with spermatozoa (sz) are common features of this region. Sertoli cell (se), peritubular myoid cell ( $m y)$ and spermatogonia ( $\mathrm{sg}$ ) are also indicated. c High magnification of a discontinuous germinal epithelium (dge); scattered cysts of spermatogonia $(s g)$ are separated by Sertoli cell ( $s e$ ) cytoplasm. Peritubular myoid cell (my), spermatozoa (sz) and phagosome (fg). d Males of group II have a well-developed medullar region (MR). Asterisks indicate the interstitial compartment. e High magnification of the medullar region; germ cell cysts at different stages of spermatogenesis form a continuous germinal epithelium (cge) in this region. Interstitial compartment (ic), Leydig cells (le or le*), granulocytes (gr) and testicular lumen (L) are also indicated. Spawning capable phase (S. capable). c GSI of males collected from November/2003 until April/2005. Values are expressed as mean \pm standard deviation. Number between brackets indicates the number of animals collected per month. Months with asterisks indicate no sampling in the period. Bars $200 \mu \mathrm{m}$ (a), $10 \mu \mathrm{m}$ (b, c), $300 \mu \mathrm{m}$ (d), $50 \mu \mathrm{m}$ (e). (Color figure online) the reproductive cycle starts (regenerating phase), $\mathrm{GtH}$ cells appeared as a small population, irregularly distributed along the PPD, basophilic, and strongly stained cells (Fig. 5a). In the developing phase, GtH cells became larger and more abundant in the PPD. In this phase, some small vacuoles are seen in the cytoplasm of these cells (Fig. 5b). In the spawning capable phase, GtH cells are poorly stained, and the main feature of this phase is the presence of large vacuoles in the cytoplasm of these cells (Fig. 5c). In the regressing phase, GtH cells became smaller, and no vacuoles are seen in their cytoplasm (Fig. 5d).

Fsh- and Lh-immunoreactive cells were detected during all reproductive phases of $P$. maculatus males (Fig. 5e-h). Apparently, Lh-immunoreactive cells became more abundant in the developing phase when compared to the other reproductive phases (Fig. 5eh). The same is observed for Fsh, although immunoreactivity for $\beta$-Lh is stronger than for $\beta$-Fsh (Fig. 5e).
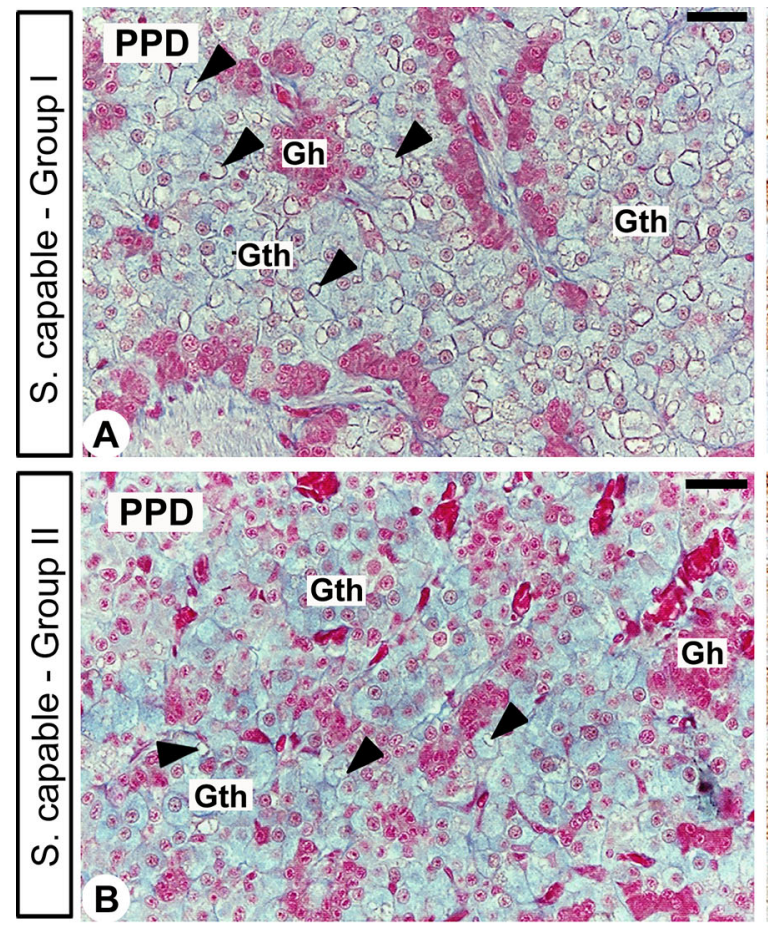

Fig. 3 Pituitary sections of S. maculatus. Sections were stained with Mallory trichrome (a, b) or submitted to immunohistochemistry reactions for $\beta$-Lh $(\mathbf{c}, \mathbf{d})$ and $\beta$-Fsh $(\mathbf{e}, \mathbf{f})$. Males of group I (a, c, e) have GtH cell with few and small vacuoles. Males of group II $(\mathbf{b}, \mathbf{d}, \mathbf{f})$ have $\mathrm{GtH}$ cells with large vacuoles in their cytoplasm. GtH cells with few and small vacuoles (group I)

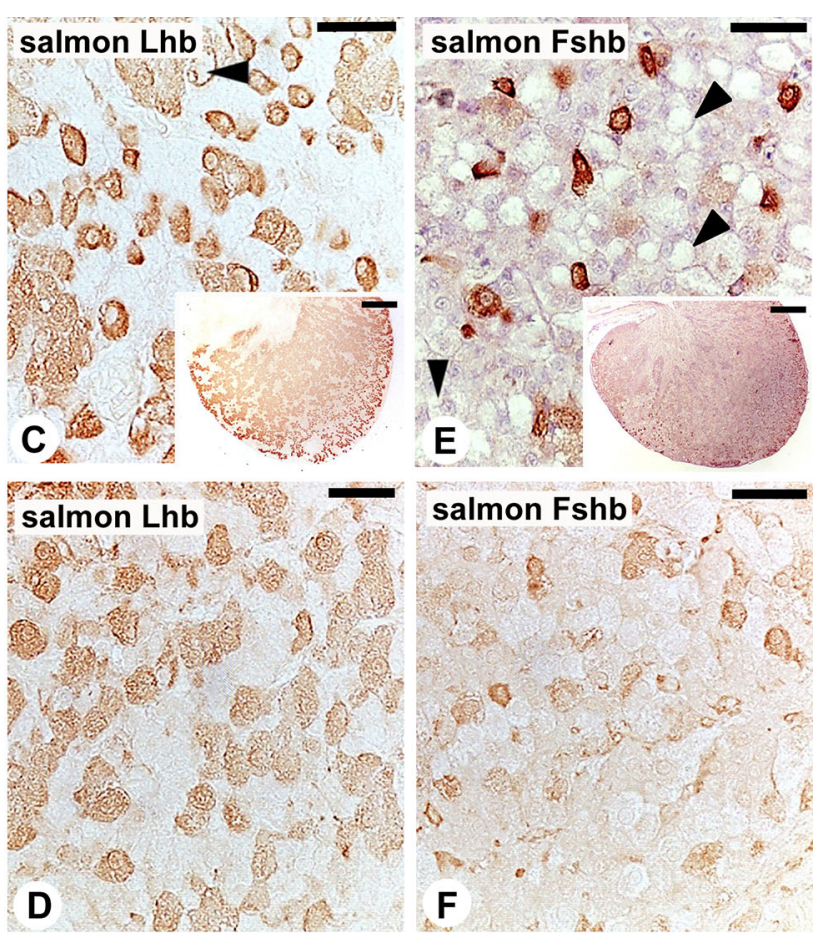

have a strong immunoreactivity for $\beta$-Lh and $\beta$-Fsh $(\mathbf{c}, \mathbf{e})$. GtH cells of group II presented a weak immunostaining for both GtHs $(\mathbf{d}, \mathbf{f})$. Pituitary sagittal sections are shown in the insets. Gonadotropic cells (GtH), Somatotropic cells (Gh), Proximal pars distalis (PPD). Arrowheads indicate vacuoles in the GtH cell cytoplasm. Bars $20 \mu \mathrm{m}(\mathbf{a}-\mathbf{f}), 200 \mu \mathrm{m}$ (inset) 

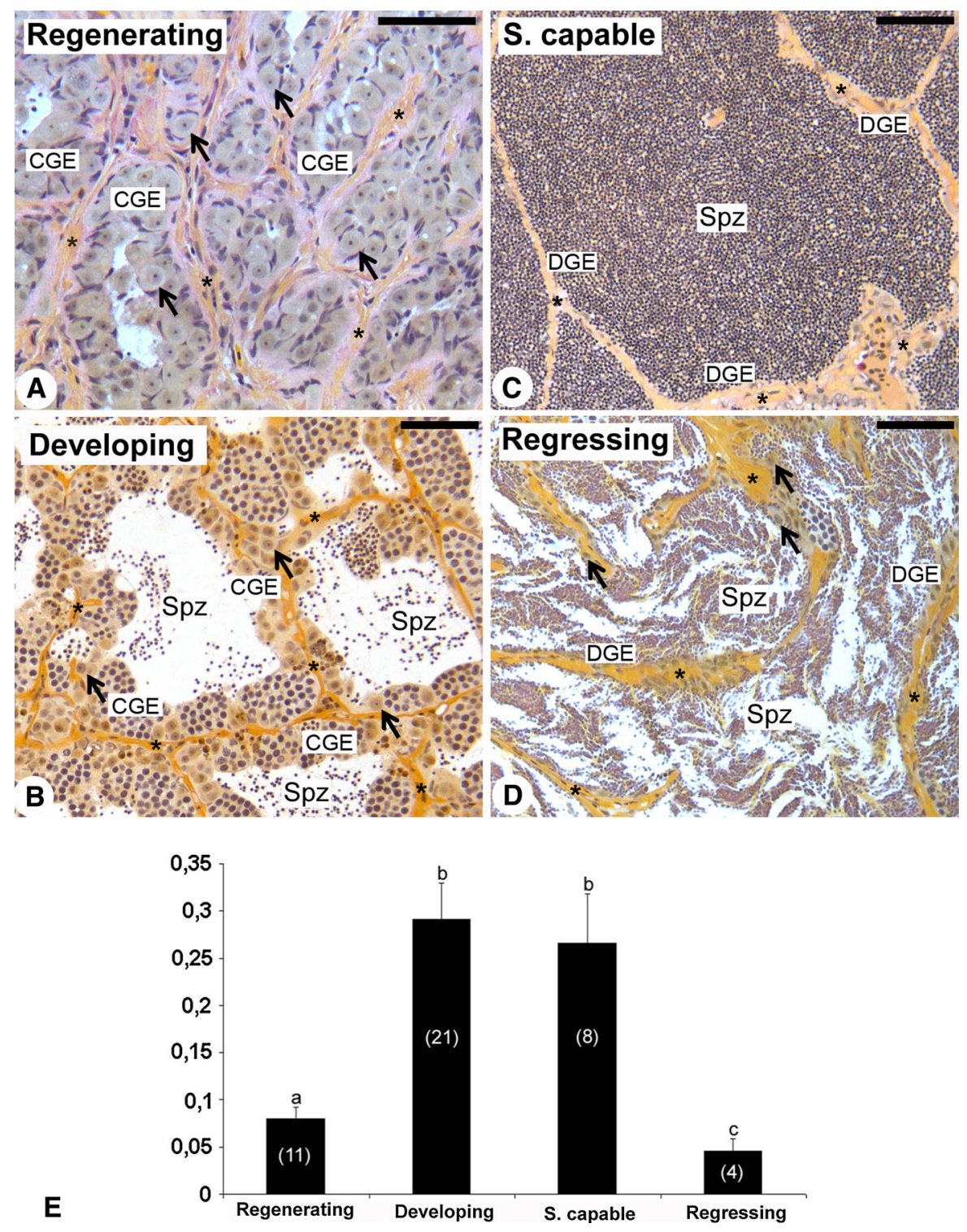

Fig. 4 Reproductive phases during the male annual cycle of $P$. maculatus (a-d). Sections were stained with PAS + Hematoxylin + Metanil Yellow. a In the regenerating phase, the germinal epithelium is continuous (CGE, continuous germinal epithelium) and formed by cysts of spermatogonia (arrow). b The developing phase is characterized by a CGE with cysts at different stages of spermatogenesis and a few spermatozoa (Spz) in the lumen. c Males at spawning capable phase have a discontinuous germinal epithelium (DGE) and large amount of

\section{Discussion}

This work describes the GtH cells and their morphological and immunohistochemical (Fsh and Lh) spermatozoa in the testicular lumen. $\mathbf{d}$ The regressing phase is characterized by a DGE with scattered cysts of spermatogonia (arrow) and less spermatozoa than in the previous phase. Asterisks indicate the interstitium in all phases. e GSI of males along the four reproductive phases. Bars represent mean \pm standard error, while different letters indicate significant differences among the phases. Number between brackets indicates the number of animals collected. Bars $50 \mu \mathrm{m}(\mathbf{a}-\mathbf{d})$. (Color figure online)

changes during the spermatogenic cycle of $S$. maculatus (continuous spermatogenesis) and P. maculatus (seasonal spermatogenesis). Moreover, we compared these changes, attempting to understand the endocrine 

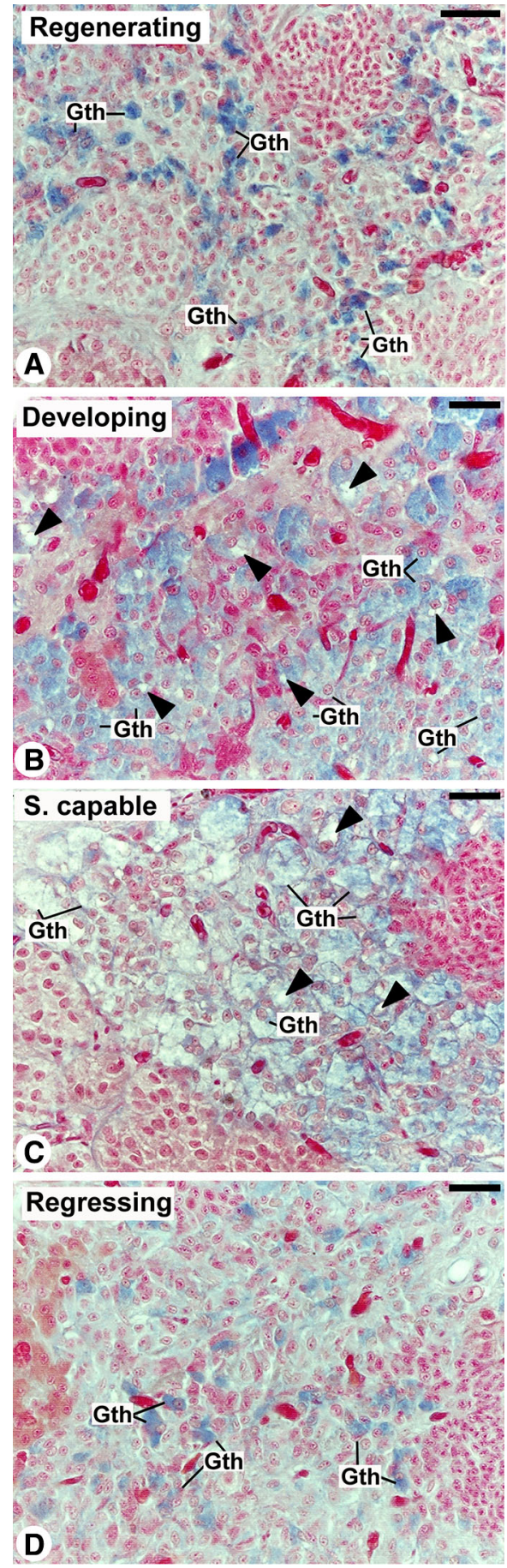

Fig. 5 Pituitary sections during the male annual reproductive cycle of $P$. maculatus. Sections were stained with Mallory trichrome (a-d) or submitted to immunohistochemistry reactions for $\beta$-Lh (e-h) and $\beta$-Fsh (inset). Note differences in gonadotropic cells $(\mathrm{GtH})$ with respect to their vacuolization and tinctorial characteristics during regenerating (a), developing (b), spawning capable (c) and regressing (d) phases.
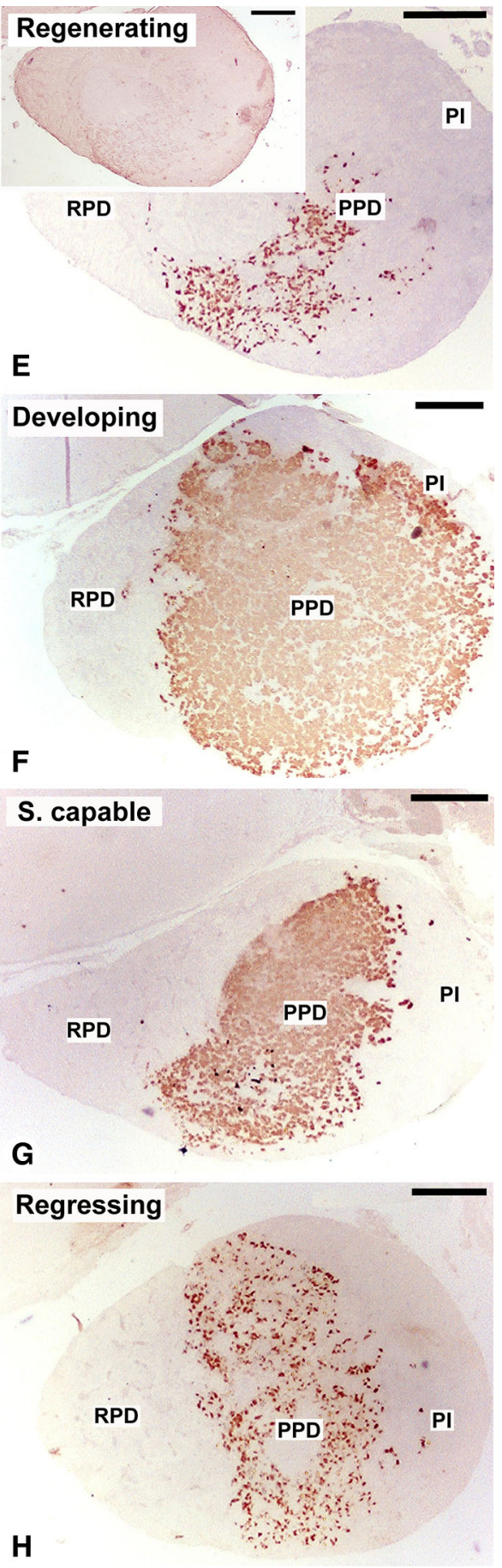

Arrowheads indicate vacuoles in the GtH cell cytoplasm. $\beta$ Lh-immunoreactive cells were detected in the regenerating (e), developing (f), spawning capable (g) and regressing (h) phase. $\beta$-Fsh immunostaining followed the same pattern, although with more background (see inset in e). Rostral pars distalis (RPD), proximal pars distalis (PPD), pars intermerdia (PI) were also indicated. Bars $20 \mu \mathrm{m}(\mathbf{b}-\mathbf{d}), 50 \mu \mathrm{m}(\mathbf{a}), 200 \mu \mathrm{m}(\mathbf{e}-\mathbf{h}$, inset $)$ 
control of two different spermatogenic cycles with respect to Fsh- and Lh-immunoreactive cells.

Histological and immunohistochemical analysis revealed that $\mathrm{GtH}$ cells are widely distributed along PPD of P. maculatus and S. maculatus, as reported previously in most of the teleost species (Borella et al. 1997, 2009; Garcia-Hernández et al. 1996; Honji et al. 2013; Shimizu et al. 2003c; Pandolfi et al. 2001a). Interestingly, GtH cells are also widely distributed at PI of P. maculatus and S. maculatus pituitary. This characteristic can be related to the expansion of $\mathrm{GtH}$ cells toward PI during gonadal maturation, as demonstrated in other species (Cambré et al. 1986).

$\mathrm{GtH}$ cells of $P$. maculatus and $S$. maculatus exhibited typical characteristics of secretory cells, such as granules and a variable number of vacuoles in their cytoplasm. One interesting characteristic, found in piscian $\mathrm{GtH}$ cells, is the presence of several vacuoles in their cytoplasm (Kaneko et al. 1986; Naito et al. 1993). These vacuoles were identified as RER cisternae (Kaneko et al. 1986; Naito et al. 1993), which become dilated as consequence of the continuous hormonal synthesis associated with a deficient transport to the Golgi complex (Young and Ball 1982). The physiological significance of these structures is still unknown. Moreover, these vacuoles were detected only in adults and not at early stages of life (García-Ayala et al. 2003; Jesus et al. 2014; Pandolfi et al. 2006).

Three populations of Fsh- and Lh-immunoreactive cells were found in S. maculatus and P. maculatus: (1) a Fsh-positive GtH cell population; (2) a Lh-positive GtH cell population and (3) a third population expressing both gonadotropins (Fsh and Lh) in the same cell. Two distinct populations of GtH cells have been reported in most of teleost species, and sometimes an additional population expressing both gonadotropins has been detected, as shown in Table 1 . Functional significance of different GtH cell populations is unknown in fish. Co-expression of Fsh and Lh in the same cell might represent a different subset of $\mathrm{GtH}$ cell or even though transitional state (stem cells?).

In this study, we have described changes in $\mathrm{GtH}$ cells during the male annual reproductive cycle of $S$. maculatus (group I and II) and P. maculatus (regenerating, developing, spawning capable and regressing phases) according to morphology and immunohistochemistry. Analyzing GtH cell morphology along continuous spermatogenesis of $S$. maculatus, we did not detect remarkable changes in GtH cells. The only clear difference is the presence of vacuoles, which become apparently more intense in animals of group I. In developing phase of $P$. maculatus (start of maturation), GtH cells also exhibited several vacuoles in their cytoplasm. Similar morphology was also observed in developing phase of Rhamdia quelen (Val-Sella and Sesso 1980) and Tridentiger obscures (Kaneko et al. 1986). This observation suggests that vacuolization is a typical characteristic of animals at maturation (developing phase). In our study, GtH cells of $P$. maculatus reached their maximum degree of vacuolization at spawning capable phase. Since vacuoles resulted from the deficient protein transport from RER to Golgi complex, vacuolization seems to be a sign of cell hypertrophy and low cellular activity. Therefore, GtH cells become gradually hypertrophic during maturation until spawning capable phase of $P$. maculatus. Feedback regulatory mechanisms might be involved in this process of vacuolization. In the regressing/regenerating phase, hypertrophic GtH cells disappeared, and GtH cells became smaller with few granules in their cytoplasm. Apoptosis of hypertrophic $\mathrm{GtH}$ cells followed by their renewal from preexisting $\mathrm{GtH}$ cells or stem cells is questions to be unraveled in this model.

Next to the morphological characteristics, we also evaluated Fsh- and Lh-immunoreactive GtH cells during the reproductive cycle of $P$. maculatus and $S$. maculatus. For $P$. maculatus, an apparent increase in Fsh and Lh-immunoreactive cell density was seen during developing and spawning capable phases. Similarly, Lh-immunoreactive cells were more numerous during the spawning capable phase of Oncorhynchus mykiss (Nozaki et al. 1990) and Fundulus heteroclitus (Shimizu et al. 2003c). The abundant number of Lh-immunopositive cells during the spawning period can be attributed to the involvement of $\mathrm{Lh}$ at the end of the reproductive cycle, such as gamete maturation and spawning (Levavi-Sivan et al. 2010; Schulz et al. 2010). Interestingly, it has been shown in Senegalese sole and Danio rerio that $\mathrm{Lh}$ drives spermiogenesis by direct activation on germ cells (Chauvigné et al. 2014). This might explain the remarkable presence of Lh-immunoreactive cells in the developing and spawning capable phases of $P$. maculatus, where spermiogenesis is more intense. For S. maculatus, we did not find clear changes in Fsh and 
Table 1 Overview about the duality of GtH cells in teleost species, mostly in adults, obtained by immunohistochemistry (IHC)

\begin{tabular}{|c|c|c|c|c|c|}
\hline Species & Order & Type of IHQ & Antibodies & Results & References \\
\hline S. maculatus & Characiformes & Single & Heterologous & $\begin{array}{l}\text { A third cell expressing both } \\
\text { GtHs }\end{array}$ & This study \\
\hline $\begin{array}{l}\text { Salminus } \\
\quad \text { brasiliensis }\end{array}$ & Characiformes & Single & Heterologous & Two distinct GtH cells & Jesus et al. (2014) \\
\hline P. maculatus & Siluriformes & Single & Heterologous & $\begin{array}{l}\text { A third cell expressing both } \\
\text { GtHs }\end{array}$ & This study \\
\hline $\begin{array}{l}\text { Oncorhynchus } \\
\text { mykiss }\end{array}$ & Salmoniformes & Single & Heterologous & Two distinct GtH cells & Nozaki et al. (1990) \\
\hline Salmo salar & Salmoniformes & Single & Homologous & Two distinct GtH cells & Nozaki et al. (1990) \\
\hline Sparus aurata & Perciformes & Single & Heterologous & Two distinct GtH cells & $\begin{array}{l}\text { García-Ayala et al. } \\
\text { (2003) }\end{array}$ \\
\hline $\begin{array}{l}\text { Seriola } \\
\quad \text { dumerilii }\end{array}$ & Perciformes & Single & Homologous & $\begin{array}{l}\text { A third cell expressing both } \\
\text { GtHs }\end{array}$ & $\begin{array}{l}\text { Garcia-Hernández } \\
\text { et al. (2002) }\end{array}$ \\
\hline $\begin{array}{l}\text { Cichlasoma } \\
\text { dimerus }\end{array}$ & Perciformes & Double & Heterologous & Two distinct GtH cells & Pandolfi et al. (2006) \\
\hline $\begin{array}{l}\text { Oreochromis } \\
\text { niloticus }\end{array}$ & Perciformes & Single/single & $\begin{array}{r}\text { Heterologous/ } \\
\text { homologous }\end{array}$ & $\begin{array}{l}\text { A third cell expressing both } \\
\text { GtHs/two distinct GtH cells }\end{array}$ & $\begin{array}{l}\text { Kasper et al. (2006), } \\
\text { Aizen et al. (2007) }\end{array}$ \\
\hline $\begin{array}{l}\text { Thunnus } \\
\text { thynnus }\end{array}$ & Perciformes & Single & Heterologous & Two distinct GtH cells & Kagawa et al. (1998) \\
\hline $\begin{array}{l}\text { Epinephelus } \\
\text { coioides }\end{array}$ & Perciformes & Single & Homologous & Two distinct GtH cells & Li et al. (2005) \\
\hline $\begin{array}{l}\text { Padogobius } \\
\text { martensi }\end{array}$ & Perciformes & Single & Heterologous & $\begin{array}{l}\text { A third cell expressing both } \\
\text { GtHs }\end{array}$ & $\begin{array}{l}\text { Cinquetti and Dramis } \\
\text { (2006) }\end{array}$ \\
\hline $\begin{array}{l}\text { Odontesthes } \\
\text { bonariensis }\end{array}$ & Atheriniformes & Single & Heterologous & Two distinct GtH cells & Miranda et al. (2001) \\
\hline Oryzias latipes & Beloniformes & Single & Heterologous & Two distinct GtH cells & Horie et al. (2014) \\
\hline $\begin{array}{l}\text { Fundulus } \\
\text { heteroclitus }\end{array}$ & Cyprinodontiformes & Single/double & Homologous & Two distinct GtH cells & $\begin{array}{l}\text { Calman et al. (2001), } \\
\text { Shimizu et al. } \\
(2003 \mathrm{c})\end{array}$ \\
\hline $\begin{array}{r}\text { Xiphoporus } \\
\text { maculatus }\end{array}$ & Cyprinodontiformes & Single & Heterologous & $\begin{array}{l}\text { A third cell expressing both } \\
\text { GtHs }\end{array}$ & $\begin{array}{l}\text { Magliulo-Cepriano } \\
\text { et al. (1994) }\end{array}$ \\
\hline $\begin{array}{l}\text { Monopterus } \\
\text { albus }\end{array}$ & Synbranchiformes & Double & Homologous & Two distinct GtH cells & Wu et al. (2012) \\
\hline
\end{tabular}

Lh-immunopositive cells during the continuous spermatogenesis; however, there is a strong immunostaining for both GtHs in group I. Considering that this species shows a continuous spermatogenesis, and GtHs are key hormones controlling testicular physiology, the presence of both Fsh and Lh along the reproductive cycle might support the continuous gametogenesis throughout the year.

S. maculatus from group I displayed testis with prominent cortical region, which reflects intense spermiogenesis and spermiation. An increased immunostaining for $\beta$-Lh and $\beta$-Fsh might suggest the role of these hormones at final maturation (spermiogenesis and spermiation). Moreover, in this group (I), an increased number of proliferating cell nuclear antigen (PCNA)-positive spermatogonia is seen, which indicates intense spermatogonial activity (PCNA data-not shown). In this context, recent studies (Nóbrega et al. 2015) have demonstrated that recombinant zebrafish Fsh triggers spermatogonial proliferation by producing stimulatory growth factors in Sertoli cells of zebrafish, $D$ rerio. Therefore, we attribute the strong $\beta$-Fsh immunostaining found in $S$. maculatus of group I to the possible commitment of Fsh on active spermatogonial proliferation in this species. Next to the role of Fsh on spermatogonial 
proliferation (Nóbrega et al. 2015), it is possible that this GtH might assume different functions in other teleost species (Shimizu et al. 2003a, b, c).

In summary, we reported morphological and immunohistochemical changes in GtH cells from two Brazilian freshwater species, S. maculatus and $P$. maculatus, with different spermatogenic cycles (continuous and seasonal, respectively). In S. maculatus, immunoreactivity for $\mathrm{Lh} / \mathrm{Fsh}$ and the presence of vacuoles were more intense in animals of group I (intense spermiation). On the other hand, in P. maculatus, Fsh/Lh-immunopositive cells and vacuoles seemed to be more abundant at the developing and spawning capable phases. These differences might reflect the type of spermatogenic cycle and dictates at the pituitary level, the rhythm of germ cell development.

Acknowledgments The authors are grateful to Dr. H. Kawauchi (School of Fisheries Sciences, Kitasato University, Iwate, Japan) for the generous gift of antibodies, Mr. Cruz A. M. Rigonati (ICB/ USP) and Antônio Vicente Salvador (IBB/UNESP) for technical support, Mr. Arno Juliano Butzge for technical help with the Figures, Dra. Irani Quagio-Grassioto (IBB/UNESP) and Fundação de Amparo à Pesquisa do Estado de São Paulo (FAPESP, 2003/11078-9).

\section{Compliance with ethical standards}

Conflict of interest The author declares no conflict of interest.

\section{References}

Agulleiro B, Garcia-Hernández MP, García-Ayala A (2006) Teleost adenohypophysis: morphofunctional and development aspects. In: Reinecke M, Zaccone G, Kapoor BG (eds) Fish endocrinology. Science Publishers, Enfield, pp 289-323

Aizen J, Kasuto H, Golan M, Zakay H, Levavi-Sivan B (2007) Tilapia follicle-stimulating hormone (FSH): immunochemistry, stimulation by gonadotropin-releasing hormone, and effect of biologically active recombinant FSH on steroid secretion. Biol Reprod 76:692-700

Arantes FP, Borçato FL, Sato Y, Rizzo E, Bazzoli N (2013) Reproduction and embryogenesis of the mandi-amarelo catfish, Pimelodus maculatus (Pisces, Pimelodidae), in captivity. Anat Histol Embryol 42:30-39

Borella MI, Gazola R, Val-Sella MV, Fava-De-Moraes F (1997) Histochemical and immunohistochemical study of the pituitary gland of the South-American teleost pacu fish Piaractus mesopotamicus (Cypriniformes, Characidae). Braz J Morphol Sci 14:219-225

Borella MI, Venturieri R, Mancera JM (2009) Immunocytochemical identification of adenohypophyseal cells in the pirarucu (Arapaima gigas), an Amazonian basal teleost. Fish Physiol Biochem 35:3-16
Brown-Peterson NJ, Wyanski DM, Saborido-Rey F, Macewicz BJ, Lowerre-Barbieri SK (2011) A standardized terminology for describing reproductive development in fishes. Mar Coast Fish Dynam Manag Ecosys Sci 2011:52-70

Calman B, Lin YW, Wallace RA (2001) Preparation and use of specific antibodies to the $\beta$-I and $\beta$-II subunits of Gonadotropic hormone from Fundulus heteroclitus pituitary. Gen Comp Endocrinol 123:203-209

Cambré ML, Verdonck W, Ollevier F, Vandesande F, Batten TF, Kühn ER (1986) Immunocytochemical identification and localization of the different cell types in the pituitary of the seabass (Dicentrarchus labrax). Gen Comp Endocrinol 61:368-375

Chauvigné F, Zapater C, Gasol JM, Cerdà J (2014) Germ-line activation of the luteinizing hormone receptor directly drives spermiogenesis in a nonmammalian vertebrate. Proc Natl Acad Sci USA 111:1427-1432

Cinquetti R, Dramis L (2006) Identification and localization of hormone-producing cells in the pituitary of male Padogobius martensi (Pisces, Gobiidae): a histochemical and immunocytochemical study. J Fish Biol 68:235-250

García-Ayala A, Villaplana M, Garcia-Hernández MP, Chaves Pozo E, Agulleiro B (2003) FSH-, LH-, and TSH-expressing cells during development of Sparus aurata L. (Teleostei). An immunocytochemical study. Gen Comp Endocrinol 134:72-79

Garcia-Hernández MP, García-Ayala A, Elbal MT, Agulleiro B (1996) The adenohypophysis of Mediterranean yellowtail, Seriola dumerilii (Risso, 1810): an immunocytochemical study. Tissue Cell 28:577-585

Garcia-Hernández MP, García-Ayala A, Zandbergen MA, Agulleiro B (2002) Investigation into the duality of gonadotropic cells of Mediterranean yellowtail (Seriola dumerilii, Risso 1810): immunocytochemical and ultrastructural studies. Gen Comp Endocrinol 128:25-35

Golan M, Biran J, Levavi-Sivan B (2014) A novel model for development, organization, and function of gonadotropes in fish pituitary. Front Endocrinol 5:182

Grandi G, Marchetti MG, Lanzoni M, Chicca M (2014) Immunocytochemical and ultrastructural identification of adenohypophyseal cells in Ctenopharyngodon idella (Cypriniformes: Cyprinidae) during gonadal differentiation. Fish Physiol Biochem 40:1115-1139

Grier H, Lo Nostro F (2000) The germinal epithelium in fish gonads: the unifying concept. In: Norberg B, Kjesbu OS, Taranger GL, Andersson E, Stefansson SO (eds) Proceedings of the 6th international symposium on the reproductive physiology of fish. University of Bergen, Norway, pp 233-236

Honji RM, Nobrega RH, Pandolfi M, Shimizu A, Borella MI, Moreira RG (2013) Immunohistochemical study of pituitary cells in wild and captive Salminus hilarii (Characiformes: Characidae) females during the annual reproductive cycle. Springerplus 2:460

Horie Y, Shimizu A, Adachi S, Kobayashi T (2014) Expression and localization of gonadotropic hormone subunits (Gpa, $\beta F s h$, and $\beta \mathrm{Lh}$ ) in the pituitary during gonadal differentiation in medaka. Gen Comp Endocrinol 204:173-180

Jesus LWO, Chehade C, Costa FG, Borella MI (2014) Pituitary gland morphogenesis and ontogeny of adenohypophyseal 
cells of Salminus brasiliensis (Teleostei, Characiformes). Fish Physiol Biochem 40:897-909

Kagawa H, Kawazoe I, Tanaka H, Okuzawa K (1998) Immunocytochemical identification of two distinct Gonadotropic cells (GTI and GTHII) in the pituitary of Bluefin Tuna, Thunnus thynnus. Gen Comp Endocrinol 110:11-18

Kaneko T, Aida K, Hanyu I (1986) Ultrastructural changes in the pituitary gonadotropes during the annual reproductive cycle of the female chichibugoby Tridentiger obscurus. Cell Tissue Res 246:137-144

Kasper RS, Shved N, Takahashi A, Reinecke M, Eppler E (2006) A systematic immunohistochemical survey of the distribution patterns of $\mathrm{GH}$, prolactin, somatolactin, $\beta$ $\mathrm{TSH}, \beta-\mathrm{FSH}, \beta-\mathrm{LH}, \mathrm{ACTH}$, and alpha-MSH in the adenohypophysis of Oreochromis niloticus, the Nile tilapia. Cell Tissue Res 325:303-313

Lamas IR, Godinho AL (1996) Reproduction in the piranha Serrasalmus spilopleura, a neotropical fish with an usual pattern of sexual maturity. Environ Biol Fishes 45:161-168

Levavi-Sivan B, Bogerd J, Mananos EL, Gomez A, Lareyre JJ (2010) Perspectives on fish gonadotropins and their receptors. Gen Comp Endocrinol 165:412-437

Li CJ, Zhou L, Wang Y, Hong YH, Gui JF (2005) Molecular and expression characterization of three gonadotropin subunits common alpha, FSH $\beta$ and $\mathrm{LH} \beta$ in groupers. Mol Cell Endocrinol 233:33-46

Magliulo-Cepriano L, Schreibman MP, Blum V (1994) Distribution of variant forms of immunoreactive gonadotropinreleasing hormone and $\beta$-gonadotropins I and II in the platyfish, Xiphophorus maculatus, from birth to sexual maturity. Gen Comp Endocrinol 94:135-150

Miranda LA, Strussmann CA, Somoza GM (2001) Immunocytochemical identification of $\mathrm{GtH} 1$ and $\mathrm{GtH} 2$ cells during the temperature-sensitive period for sex determination in pejerrey, Odontesthes bonariensis. Gen Comp Endocrinol 124:45-52

Mukai T, Oota Y (1995) Histological changes in the pituitary, thyroid gland and gonads of the fourspine sculpin (Cottus kazika) during downstream migration. Zool Sci 12:91-97

Naito N, Suzuki K, Nozaki M, Swanson P, Kawauchi H, Nakai Y (1993) Ultrastructural characteristics of two distinct gonadotropes (GTH I- and GTH II-cells) in the pituitary of rainbow trout Oncorhynchus mykiss. Fish Physiol Biochem 11:241-246

Nóbrega RH, Quagio-Grassiotto I (2007) Morphofunctional changes in Leydig cells throughout the continuous spermatogenesis of the freshwater teleost fish, Serrasalmus spilopleura (Characiformes, Characidae): an ultrastructural and enzyme study. Cell Tissue Res 329:339-349

Nóbrega RH, Morais RDVS, Crespo D, de Waal PP, França LR, Schulz RW, Bogerd J (2015) Fsh stimulates spermatogonial proliferation and differentiation in zebrafish via Igf3. Endocrinology 156:3804-3817

Nozaki M, Naito N, Swanson P, Dickhoff WW, Nakai Y, Suzuki K, Kawauchi H (1990) Salmonid pituitary gonadotrophs. II. Ontogeny of GTH I and GTH II cells in the rainbow trout (Salmo gairdneri irideus). Gen Comp Endocrinol 77:358-367

Pandolfi M, Paz DA, Maggese C, Meijide FJ, Vissio PG (2001) Immunocytochemical localization of different cell types in the adenohypophysis of the cichlid fish Cichlasoma dimerus (Heckel, 1840). Biocell 25:35-42

Pandolfi M, Lo Nostro FL, Shimizu A, Pozzi AG, Meijide FJ, Vazquez GR, Maggese MC (2006) Identification of immunoreactive FSH and LH cells in the cichlid fish Cichlasoma dimerus during the ontogeny and sexual differentiation. Anat Embryol 211:355-365

Pierce JG, Parsons TF (1981) Glycoprotein hormones: structure and function. Annu Rev Biochem 50:465-495

Quintero-Hunter I, Grier H, Muscato M (1991) Enhancement of histological detail using metanil yellow as counterstain in periodic acid Schiff's hematoxylin staining of glycol methacrylate tissue sections. Biotech Histochem 66:169-172

Santana JC, Quagio-Grassiotto I (2014) Extracellular matrix remodeling of the testes through the male reproductive cycle in Teleostei fish. Fish Physiol Biochem 40:18631875

Schulz RW, de Franca LR, Lareyre JJ, Le Gac F, ChiariniGarcia H, Nobrega RH, Miura T (2010) Spermatogenesis in fish. Gen Comp Endocrinol 165:390-411

Shimizu A, Kagawa H, Tanaka H (2003a) Immunocytochemical identification of gonadotrophs (FSH cells and LH cells) in various perciform fishes using antisera raised against synthetic peptides. Fish Physiol Biochem 28:109-110

Shimizu A, Sakai T, Nashida K, Honda H (2003b) Universal antisera for immunocytochemical identification of two different gonadotrophs in acanthopterygian fishes. Fish Physiol Biochem 29:275-287

Shimizu A, Tanaka H, Kagawa H (2003c) Immunocytochemical applications of specific antisera raised against synthetic fragment peptides of mummichog GtH subunits: examining seasonal variations of gonadotrophs (FSH cells and LH cells) in the mummichog and applications to other acanthopterygian fishes. Gen Comp Endocrinol 132:35-45

Val-Sella MV, Sesso A (1980) Morphometric evaluation of the number of gonadotrophic cells of the teleost Rhamdia hilarii in the maturation, mature and spent stages of the gonadal cycle. Acta Zool 61:133-139

Vongvatcharanon U, Kirirat P, Suwanjarat J, Boonyoung P (2005) Alteration of gonadotrophs in the pituitary gland during the annual reproductive cycle of the adult female sand goby (Oxyeleotris marmoratus). J Sci Technol 27:437-445

Weltzien FA, Andersson E, Andersen O, Shalchian-Tabrizi K, Norberg B (2004) The brain-pituitary-gonad axis in male teleosts, with special emphasis on flatfish (Pleuronectiformes). Comp Biochem Physiol A: Mol Integr Physiol 137:447-477

Wildner DD, Grier H, Quagio-Grassiotto I (2013) Female germ cell renewal during the annual reproductive cycle in Ostariophysians fish. Theriogenology 79:709-724

Wu Y, He Z, Zhang L, Jiang H, Zhang W (2012) Ontogeny of immunoreactive $\mathrm{Lh}$ and Fsh cells in relation to early ovarian differentiation and development in protogynous hermaphroditic ricefield eel Monopterus albus. Biol Reprod 86(93):1-9

Young G, Ball JN (1982) Ultrastructural changes in the adenohypophysis during the ovarian cycle of the viviparous teleost Poecilia latipinna. I. The gonadotrophic cells. Gen Comp Endocrinol 48:39-59 